\title{
Mesenchymal stem cells in idiopathic pulmonary fibrosis
}

Review

\author{
Xiaohong $\mathrm{Li}^{1}$, Shaojie Yue ${ }^{2}$ and Ziqiang Luo ${ }^{1}$ \\ ${ }^{1}$ Department of Physiology, Xiangya School of Medicine, Central South University, Changsha, China \\ 2 Department of Neonatology, Xiangya Hospital, Central South University, Changsha, China \\ Correspondence to: Ziqiang Luo, email: luozq1962@163.com \\ Keywords: idiopathic pulmonary fibrosis, mesenchymal stem cells, mobilization, secretome, immunomodulation \\ Received: March 03, $2017 \quad$ Accepted: May 07, 2017 \\ Published: May 23, 2017
}

Copyright: Li et al. This is an open-access article distributed under the terms of the Creative Commons Attribution License 3.0 (CC BY 3.0), which permits unrestricted use, distribution, and reproduction in any medium, provided the original author and source are credited.

\section{ABSTRACT}

Idiopathic pulmonary fibrosis (IPF) is a major cause of respiratory failure in critically ill patients and common outcome of various lung interstitial diseases. Its mortality remains high, and no effective pharmacotherapy, in addition to artificial ventilation and transplantation, exists. As such, the administration of mesenchymal stem or stromal cells (MSCs) is currently investigated as a new therapeutic method for pulmonary fibrosis. Clinical trials on MSC-based therapy as a potential treatment for lung injury and fibrosis are also performed. MSCs can migrate to injured sites and secrete multiple paracrine factors and then regulate endothelial and epithelial permeability, decrease inflammation, enhance tissue repair, and inhibit bacterial growth. In this review, recent studies on stem cells, particularly MSCs, involved in alleviating lung inflammation and fibrosis and their potential MSC-induced mechanisms, including migration and differentiation, soluble factor and extracellular vesicle secretion, and endogenous regulatory functions, were summarized.

\section{INTRODUCTION}

Idiopathic pulmonary fibrosis (IPF) is a chronic, progressive, and irreversible lower respiratory disease characterized by diffuse alveolar inflammation and alveolar structural disorder, and this condition eventually leads to pulmonary interstitial fibrosis [1]. Its main pathological changes include severely damaged alveolar structure, numerous proliferated fibroblasts, and extensive extracellular matrix (ECM) deposition [2, 3]. Pulmonary fibrosis $(\mathrm{PF})$ is a serious respiratory disease whose main clinical manifestation is progressive dyspnea, which results in respiratory failure and death. The incidence of IPF increases annually, its mortality is high, and its median survival is approximately three to five years after diagnosis, but these observations are poorer than those of many cancers [4-6]. However, IPF is quite difficult to diagnose, and no standard treatment is available for patients with IPF [7]. Current treatment mainly involves lung transplantation, mechanical ventilation, and oxygen therapy. Although pirfenidone and nintedanib elicit therapeutic effects on lung functional deterioration and disease progression in patients with IPF, these drugs fail to induce damaged tissue regeneration [8]. As new therapeutic agents for diseases, stem cells, including mesenchymal stem cells (MSCs), have been widely investigated [9]. In phase I clinical trials, MSCs are used as cell therapy for pulmonary diseases because these MSCs, which are a class of multipotent stem cells, can be transdifferentiated, cloned, and self-renewed in vitro $[10,11]$. MSCs also help ameliorate inflammation and moderate the deterioration of PF [12].

\section{PATHOLOGIC LESIONS OF IPF}

IPF is an interstitial pulmonary disease characterized by dysfunction of epithelial cells, activation of fibroblasts, accumulation of myofibroblasts, and vast deposition of ECM [3]. Fibroblastic foci are important pathological and unique morphological hallmark lesions in IPF, in which fibroblasts and myofibroblasts are possibly involved in tissue remodeling and matrix deposition [13]. The pathologic degree of fibroblast foci is closely related to the prognosis of patients with IPF. Active fibroblasts in PF are formed via at least three mechanisms, namely, proliferating resident fibroblasts, epithelial-to-mesenchymal transition (EMT), and bone marrow (BM)-derived fibrocytes. 


\section{Proliferation of resident fibroblasts}

The proliferation and accumulation of resident fibroblasts play a significant role in IPF pathogenesis and constitute a key source of interstitial collagens in fibroblastic foci. Under the action of transforming growth factor- $\beta$ (TGF- $\beta$ ), resident fibroblasts can be activated and differentiated into myofibroblasts, then accumulating in damaged lung tissues [3]. Intrapulmonary fibroblasts increase the expression of collagen genes and mesenchymal proteins, such as vimentin and $\alpha$-smooth muscle actin ( $\alpha$-SMA), through $\mathrm{Wnt} / \beta$-catenin signaling and take part in PF development [14]. Myofibroblasts, which express $\alpha$-SMA, are the primary inducers of increasing the expression of lung collagen proteins and thus promote ECM deposition and the contractility of lung tissue [15].

\section{Epithelial-mesenchymal transition}

Alveolar epithelial cell (AEC)-derived fibroblasts are another component in fibroblastic foci during PF through EMT, which involves sustained missing of epithelial markers, including E-cadherin, keratin, and continuously increased expression of mesenchymal markers, including N-cadherin, vimentin, $\alpha$-SMA [1620]. The establishment of EMT is also implicated in the interaction of TGF- $\beta$ with receptor tyrosine kinase (RTK) by activating the Ras/ERK/MAPK signaling pathway [17, $21,22]$. TGF- $\beta$ is a key factor in EMT process during PF development. A previous study provided direct evidence for the involvement of TGF- $\beta$ in EMT process during PF by generating transgenic mice, in which type II AECs were labeled with $\beta$-galactosidase ( $\beta$-gal) [16]. In the PF model of overexpressing TGF- $\beta 1$, fibroblasts positive for vimentin were mostly $\beta$-gal-positive cells [16]. However, phenotypic changes are fully reversible after inducing factors are removed [18], and EMT contributing to lung fibrosis in vivo remains controversial [23]. Endothelial cells of pulmonary blood vessels are one of the major cell types of structural cells and implicated in maintaining homeostasis in lungs [24]. In vitro studies have reported that endothelial cells may act as a source of $\alpha$-SMApositive mesenchymal cells and can produce type I collagen (Col I) $[25,26]$. Hashimoto et al. demonstrated that endothelial cells can stimulate the production of a large number of fibroblasts in bleomycin (BLM)-induced PF model, and the underlying mechanism of EMT in endothelial cells is involved in Ras and TGF- $\beta$ activation [27].

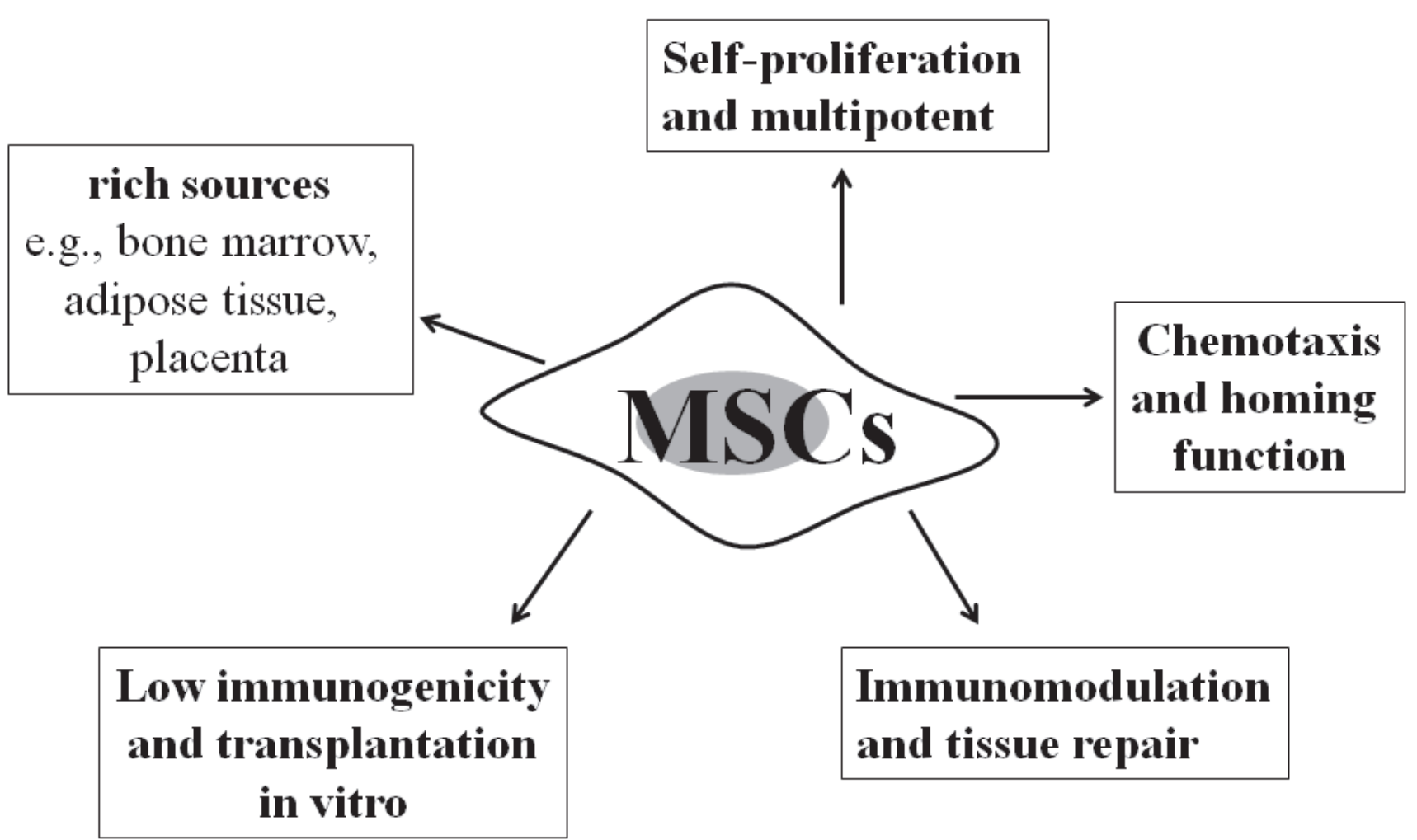

Figure 1: Properties of mesenchymal stem cells. Mesenchymal stem cells (MSCs), as a class of multipotent stem cells, possess multiple properties: (i) self-proliferation and differentiation potential; (ii) rich sources, e.g., bone marrow, adipose tissue, and placenta; (iii) low immunogenicity and transplantation in vitro; (iv) chemotaxis and homing function; and (v) immunomodulation and tissue repair. These characteristics are crucial for MSCs to be applied as a therapeutic modality in idiopathic pulmonary fibrosis (IPF). 


\section{Bone marrow-derived fibrocytes}

Experimental data have provided evidence that some fibroblasts in fibroblast foci can be derived from BM progenitor cells (BMPCs). The circulating peripheral blood-derived fibroblasts (called "fibrocytes") have fibroblast-like properties and express $\mathrm{CD} 45^{+}$collagen $\mathrm{I}^{+} \mathrm{CXCR}^{+}[28,29]$. BM-derived fibrocytes can be chemotactically gathered to damaged lung tissue sites and play a key role in the establishment of fibrosis at the injured sites [28, 30, 31]. Clinical examination showed that fibrocytes increased in peripheral blood, bronchoalveolar lavage fluid (BALF), and lung tissues of IPF patients, and this phenomenon was associated with poor patient prognosis $[32,33]$. Animal experiments also showed that lung fibrocytes began to increase on the second day after intratracheal administration of BLM, peaking on the eighth day, and still significantly higher than that of the control group until the 20th day [28]. The homing of circulating fibrocytes to fibrotic lung is dependent on the CXCL12/ CXCR4 biological axis. Treatment of mice with CXCL12 antibody or CXCR4 antagonist with BLM-induced lung injury inhibited circulating fibrocytes from migrating to the damaged lung tissues and significantly attenuated lung fibrosis [28, 34-36]. Some studies indicated that mouse fibrocytes to traffic to lung via the CCL12/CCR2 axis in the FITC-induced PF model $[37,38]$ and via the CCL3/ CCR5 axis in BLM-induced PF [39].

\section{ESSENTIAL PROPERTIES OF MSCS}

BM can also generate mesenchymal stem cells (bone marrow-derived mesenchymal stem cells, BMMSCs), which have protective effects against the PF. Friedenstein et al. first discovered MSCs, which are a class of multipotent stem cells with self-proliferation and differentiation potential, in 1968 [40, 41]. MSCs can be obtained from different types of tissues, such as BM, adipose tissue, and umbilical cord blood, and BM-MSCs are the main sources for stem cell therapy [40]. Three criteria have been established for isolating and cultivating MSCs [42-44]: i) MSCs exhibit fibroblastic morphology, clonogene, and plastic adherence when cultured in

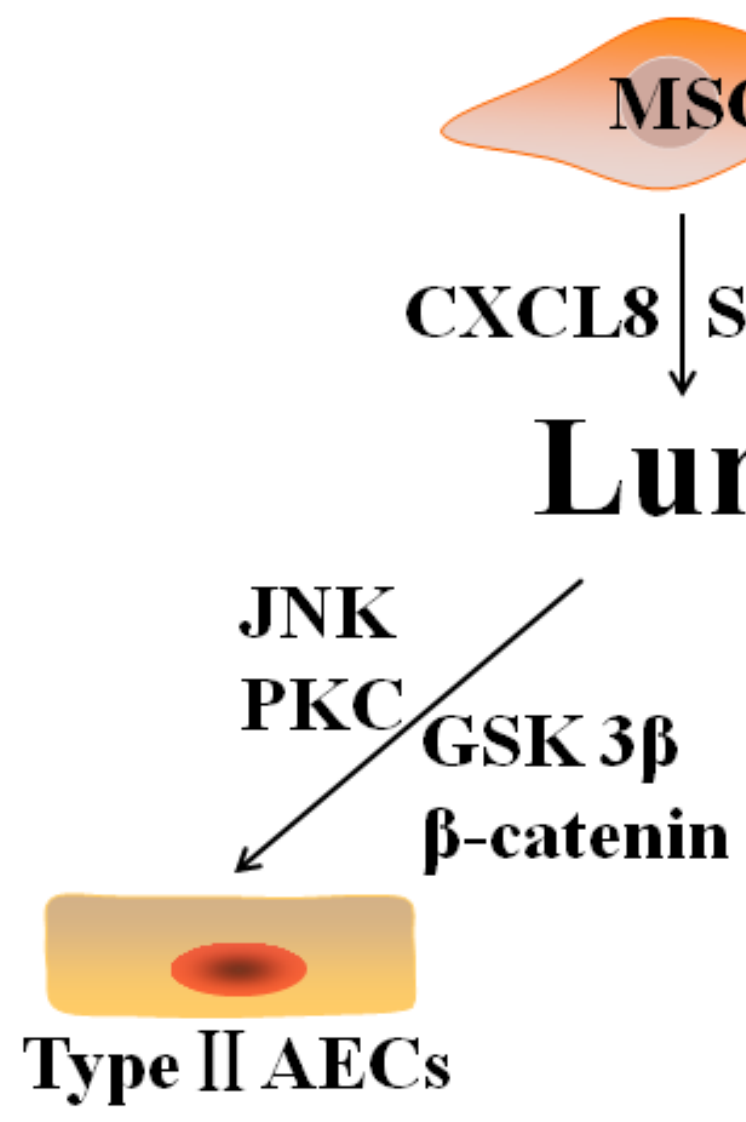

Figure 2: Various differentiations of mesenchymal stem cells after homing to the injured lung. Mesenchymal stem cells (MSCs) home to lung in response to injury via chemokines and receptors (CXCL8, SDF-1, and CXCR4). On one hand, MSCs differentiate into type II AECs and ameliorate pulmonary fibrosis through canonical Wnt pathway (GSK-3 $\beta$ and $\beta$-catenin) and noncanonical Wnt pathway (JNK and PKC). On the other hand, MSCs differentiate into fibroblasts and promote pulmonary fibrosis by activating Wnt/ $\beta$ catenin signaling. Abbreviations: AECs: alveolar epithelial cells; CXCR4: C-X-C chemokine receptor type 4; CXCL8: interleukin-8; SDF1: stromal cell derived factor-1; JNK: c-Jun N-terminal kinase; PKC: protein kinase C; GSK: glycogen synthase kinase. 
standard tissue culture conditions; ii) differentiate into adipocytes, osteoblasts, and chondrocytes in vitro; and iii) express certain cell surface markers such as CD44, Sca-1, CD29, and CD90 but not CD45, CD34, CD14, and CD11b. Moreover, MSCs possess low immunogenicity, can be used for xenogenous transplantation, and are widely used in basic research and treatment of many diseases due to its immunomodulation and tissue repair function [45] (Figure 1). With further research development, MSC transplantation is increasingly used in the treatment of clinical diseases, such as lung diseases [45], hepatic failure [46], myocardial infarction [47], diabetes [48], sepsis [49], and acute renal failure [50].

Exogenous MSC transplantation has achieved the desired effects, and no transplant-related adverse reaction has been observed in lung-injury animals in some small clinical trials. However, its safety and efficacy in humans remain questionable due to the difference between animals and human and the small sample size of clinical trials. Concurrently, transplant-related adverse reactions have been observed in patients under clinical trials. In clinical research in which BM-MSCs were used for treating osteogenesis imperfecta (OI), one of six children patients who had undergone standard BM transplantation for severe OI had clinically significant toxicity [51]. Moreover, MSC-based treatments pose other risks, such as tumorigenesis due to weakened immune system and enhanced angiogenesis [52].

In recent years, research on the mobilization of endogenous stem cells from BM for tissue repair has attracted people's attention [53, 54]. The BM acts as a repository for a variety of stem cell populations, which are mobilized at varying degrees into the peripheral circulation after damage [55]. Endogenous MSCs from $\mathrm{BM}$ can be mobilized and have the capability to proceed from the circulatory system to various, experimental, and damaged tissues, where they can promote to tissue repair and regeneration by secreting various paracrine factors and directly differentiating into different cells [54-57]. Research showed that approximately two EPCs exist in $10^{7}$ mononuclear cells [58], whereas 0.5-5 MSCs exist in $10^{5}$ mononuclear cells [59]. Rojas et al. reported

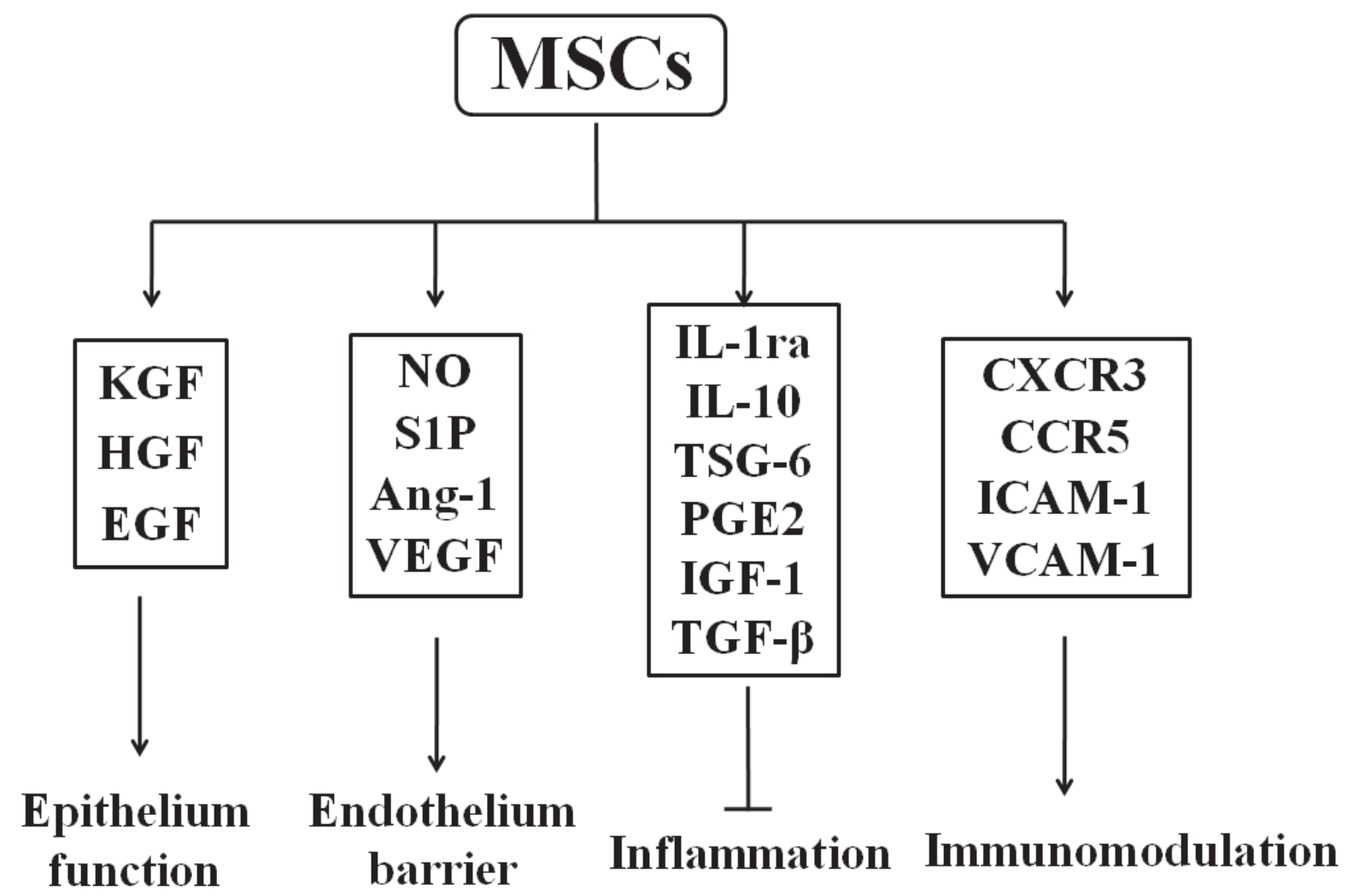

Figure 3: Secretome of mesenchymal stem cells. After activation, mesenchymal stem cells (MSCs) can produce various growth factors (KGF, HGF, and EGF) to protect epithelium function. MSCs enhance endothelium barrier via NO, S1P, Ang-1, and VEGF and secrete anti-inflammatory cytokines, such as IL-1ra, IL-10, and TSG-6. Moreover, MSCs achieve immunomodulating function through chemokines and receptors (ICAM-1, VCAM-1, and CXCR3). These factors are crucial components for function regulation and tissue repair by MSCs. Abbreviations: KGF: keratinocyte growth factor; HGF: hepatocyte growth factor; EGF: epidermal growth factor; NO: nitric oxide; S1P: sphingosine-1-phosphate; Ang-1: angiopoietin-1; VEGF: vascular endothelial growth factor; TSG-6: TNF- $\alpha$ stimulated gene/ protein 6; PGE2: prostaglandin E2; IL-1ra: IL-1 receptor antagonist; IL-10: interleukin-10; IGF-1: insulin like growth factor 1; TGF- $\beta$ : transforming growth factor- $\beta$; ICAM-1: intercellular adhesion molecule-1; VCAM-1: vascular cell adhesion molecule-1. 
that busulfan inhibited BM function before duplicating PF and aggravated the degree of PF in mice model [60]. The administration of $N$-acetylcysteine-pretreated human embryonic MSCs protects against BLM-induced lung injury [61]. Oncostatin M-preconditioned MSCs alleviated BLM-induced PF through paracrine effects of the hepatocyte growth factor (HGF) [62]. These results imply that normal BM function and/or trying to improve MSCs function play important roles in lung injury repair. Granulocyte colony-stimulating factor (G-CSF) promotes stem cell mobilization via downregulating the expression of stromal cell-derived factor (SDF)-1 and increasing CXCR4 in BM [63]. Studies found that transplantation of BM stem cells as well as mobilization by G-CSF promotes recovery after spinal cord injury in rats [64]. G-CSF had a protective effect against BLM-induced lung injury and fibrosis [65]. In newborn rat model of highoxygen induced-lung injury, G-CSF had a protective effect for alveolar growth restriction caused by high oxygen and improved the serum vascular endothelial growth factor (VEGF) level and promoted lung blood vessel growth [66]. However, other research showed that G-CSF enhanced BLM-induced lung toxicity through a mechanism that probably involved neutrophils [67], and serum concentrations of G-CSF was significantly higher in IPF patients than that of the control group [68]. Meanwhile, the number of BM-MSCs decreased in BLM induced-PF mice model [69]. SDF-1-TR1 and CXCR4 mRNA expressions were significantly increased in BMMSCs of IPF patients compared with that of controls [70]. The protective effects of BM-derived mononuclear cells from donors of acute respiratory distress syndrome markedly decreased [71]. These results suggest that BM function diminishes in the development of lung injury.

\section{ROLES AND MECHANISMS OF MSCS IN PULMONARY FIBROSIS}

MSCs are also used to treat PF [9]. BM-MSC transplant significantly reduced lung injury and fibrosis in the animal BLM-induced PF models [72]. In 2003, Ortiz reported that BM-MSC injection $\left(5 \times 10^{5} /\right.$ mouse in $200 \mu \mathrm{l}$ of PBS) through the jugular vein immediately after challenge with BLM can significantly reduce PF [73]. In $\mathrm{SiO}_{2}$-induced IPF mice model, human mesenchymal stem cell (hMSC) transplantation directly replaced fibrosis with normal lung cells and reduced IPF symptom, such as collagen deposition and inflammation [74]. BLMinduced lung injury and fibrosis were significantly reduced by injection of BM-MSCs by downregulating proinflammatory and angiogenic cytokines and nitric oxide metabolites after 4 days of BLM inhalation. [75]. Zhao et al. also proved the therapeutic effects of BM-MSC engraftment in BLM-induced lung damage in rats [76]. The cyclophosphamide alone did not improve PF and may even aggravate PF, but the combination with BM-
MSCs can protect against BLM-induced lung fibrosis in mice [77]. Moreover, data from MSC-based clinical trials support the safety of a single infusion of hMSC in patients with IPF [78].

\section{Homing and migration}

IPF is an epithelial-driven disease [79]. The recurrent injury and abnormal repair of AECs disturb normal epithelial-fibroblast interactions and play major roles in promoting the fibrotic process [80]. When type I AECs are damaged and/or missing, type II AECs experience hyperplastic proliferation and differentiation into type I AECs to blanket the uncoated basilar membranes [3]. Under pathologic conditions, the resident fibroblasts accumulate and differentiate into myofibroblasts under the action of TGF- $\beta$ in these damaged areas.

Some results suggested that BM-MSCs was homing to the lungs after damage, exhibiting epithelioid phenotypes and reducing inflammation and collagen deposition in BLM-induced animal models [73, 81]. Akram et al. found that hMSCs showed a strong migratory response to AECs injury in a $3 \mathrm{D}$ direct-contact wound repair model [82]. The migration of BM-MSCs are mediated by some chemotactic factors and their receptors. The chemokine SDF-1 is crucial for migration to injured tissues via interacting with its cognate receptor CXCR4 on the cellular surface [83]. Xu et al. found SDF-1 significanly promoted the chemotactic migration of BMMSCs, but this effect was mimicked by lungs extracts from mice after BLM treatment and was completely inhibited by a synthetic specific CXCR4 antagonist, that is, TN14003 [36]. SDF-1 and CXCR4 were increased in lungs of IPF patients compared to normal human lungs, and the concentration of SDF-1 in serum and BALF and the expression level of CXCR4 in lungs were elevated in BLM-induced animal models [36]. On day 7 after BLM challenge, the SDF-1 $\alpha$ mRNA levels in the lungs increased significantly compared with saline groups and remained on day 14 [29]. SDF-1 expression was also increased in the lungs of patients with idiopathic interstitial pneumonia [84]. Another study showed chemokine CXCL8 (interleukin-8) also promoted the migration of hMSCs [85] (Figure 2).

\section{Differentiation}

Furthermore, after homing to injured lungs, MSCs can differentiate into type II AECs and be involved in the renewal of the alveolar epithelium in vitro and in vivo [86-88]. MSC differentiation into type II AECs is mainly mediated by the Wnt pathway [89]. Liu et al. found that

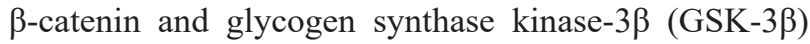
in the canonical Wnt pathway were activated during the differentiation of mouse MSCs into type II AECs [86]. 
Overexpression of $\beta$-catenin in mouse MSCs to activate canonical Wnt/ $\beta$-catenin pathway further improved their protective effect against epithelial impairment and therapeutic effects for ARDS in mice [87]. Further studies indicated that Wnt5a contributes to MSC differentiation into type II AECs through noncanonical c-Jun N-terminal kinase (JNK) or protein kinase C (PKC) signaling in vitro [88] (Figure 2).

However, MSCs playing a role in resistance to PF through differentiation into epithelial cells remains controversial. In HCl-induced ALI models, MSCs did not improve the pathologic changes of ALI and PF [90]. The researchers found that the activation of canonical Wnt $/ \beta$ catenin signaling induced most MSCs to differentiate into fibroblasts or myofibroblasts, and that block this signal after MSC transplantation ameliorated PF and improved pulmonary function in vivo. Tang et al. also showed that BM-MSCs induce $\alpha$-SMA-positive myofibroblasts in a transplanted BM model [91]. MSCs, which were administered to mice during the fibrotic stage of radiation- induced PF model, differentiated into fibroblast-like phenotype and aggravated the fibrotic lesion [92]. MSCs isolated from BLM-injured mice lungs were also more likely to differentiate into fibroblasts in vitro [93] (Figure 2).

\section{MSC-derived secretome}

MSCs with therapeutic effects on injured lungs have been extensively investigated because of their low engraftment and differentiation after exogenous administration [94, 95]. Although MSCs can migrate to the damaged lung tissues and have differentiation function, these roles are insignificant. The mechanism of MSC resistance to PF mainly depends on the function of their paracrine factors and immune adjustment. Interestingly, MSC-derived conditioned medium (MSC-CM) can also exert their protective effects against BLM-induced lung injury and fibrosis [96]. In the BLM-induced rat

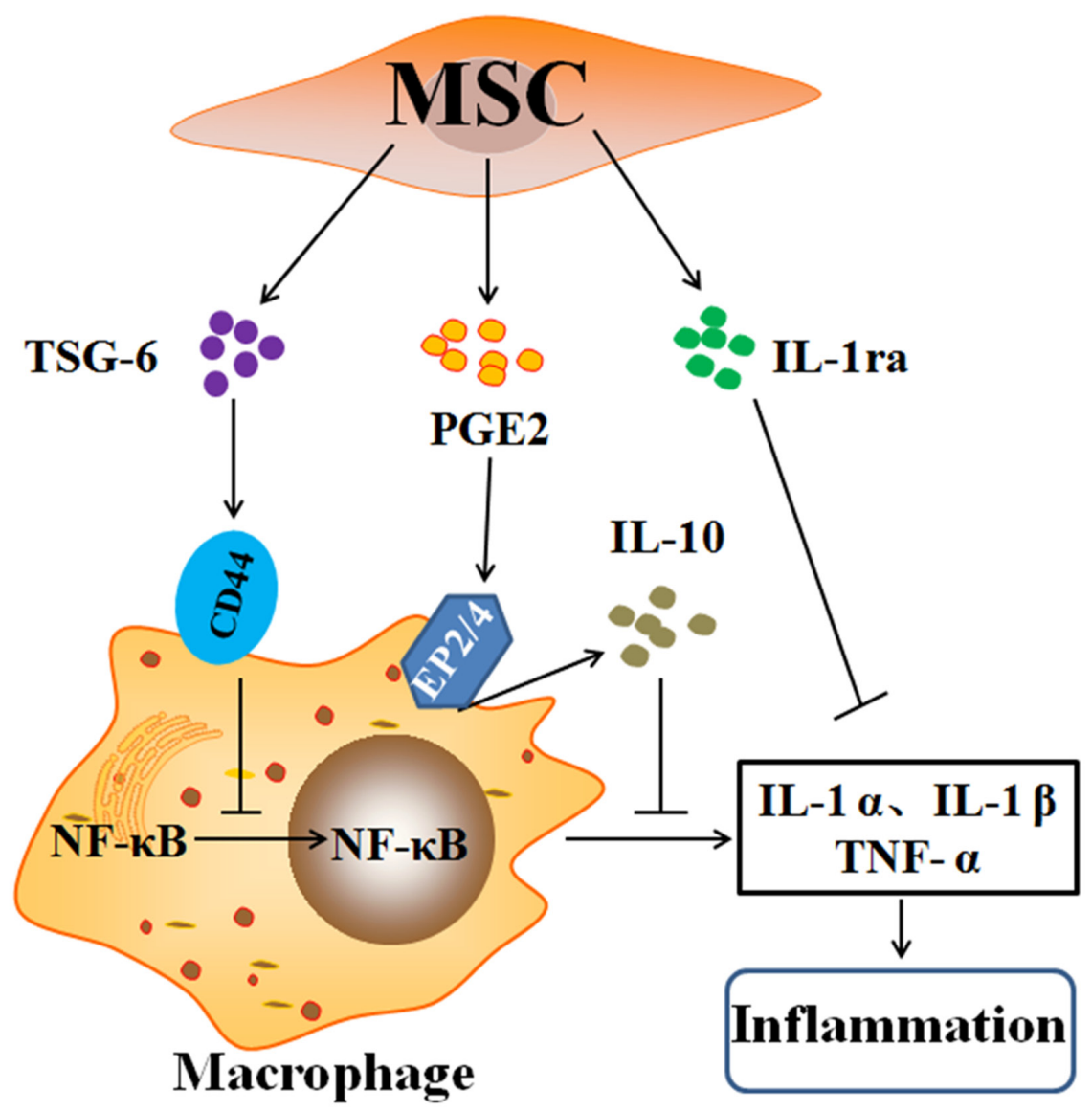

Figure 4: Anti-inflammatory factors secreted by mesenchymal stem cells. The anti-inflammatory effects of the mesenchymal stem cells (MSCs) are largely explained by the cells being activated to secrete TSG-6, PGE2, and IL-1ra on resident macrophages. TSG-6 suppressing the activation and translocation of the (NF- $\mathrm{KB})$ complex to the nucleus and decreasing the secretion of the pro-inflammatory cytokines, namely, TNF- $\alpha$, IL- $1 \alpha$, and IL-1 $\beta$, is dependent on CD44 expression. PGE2 bind to EP2 and EP4 receptors on macrophages and change macrophages to the phenotype that secretes IL-10. IL-1ra secreted from MSCs inhibit the production of TNF- $\alpha$ through IL-1 $\alpha-$ activated macrophages. Abbreviations: TNF- $\alpha$ : tumor necrosis factor- $\alpha$; IL: interleukin; TSG-6: TNF- $\alpha$ stimulated gene/protein 6; PGE2:

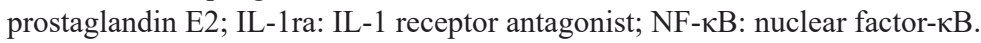


model, MSC-CM was proved to prevent PF because of reducing pulmonary inflammation, fibrosis score, collagen deposition, and cell apoptosis [96]. MSC-CM protected A549, namely human non-small-cell lung cancer epithelial cells, from BLM-induced apoptosis [96]. At present, one emerging concept is MSCs having paracrine roles in lung injury repair and regeneration. MSCs have been proposed to possess the capacity to secrete a broad range of bioactive molecules, such as growth factors, cytokines, and chemokines [97-99]. These bioactive molecules regulate local immune response to establish a regenerative microenvironment and subsequently inhibit inflammation and repair the injured tissues (Figure 3).

\section{Growth factors}

MSC-derived growth factors play essential roles in the repair of alveolar epithelial cells and pulmonary vascular endothelial cells and restoration or maintenance of lung permeability following injury [100]. Keratinocyte growth factor (KGF), the seventh member of the FGF family (FGF7), is an important epithelial-specific growth factor secreted by BM-MSCs [101]. KGF can decrease pulmonary edema, the expression of TGF- $\beta$ and platelet-derived growth factor-BB (PDGF-BB), and the loss of type II AEC in BLM-induced PF [102]. BM stem cells expressing KGF via an inducible lentivirus protects against BLM-induced PF [103]. Intratracheal administration of MSC-CM one hour following injury decreased inflammation and prevented the influx of neutrophils and pulmonary edema by restoring lung protein permeability and increasing alveolar fluid absorption in the injured alveolus; however, blocking KGF expression by using a neutralizing antibody abrogated their therapeutic properties [101]. Another epithelialspecific growth factors secreted by MSCs are HGF and epidermal growth factor (EGF) [100]. MSCs prerteated with hypoxia had better therapeutic effects in BLMinduced PF and improved the survival rate of transplanted MSCs because of increasing HGF in part [104]. Oncostatin $\mathrm{M}$ strengthened the anti-lung fibrosis effect of MSCs through paracrine HGF [62]. Moreover, HGF gene knockdown in the MSCs significantly diminished the protective effects of MSCs on the injured lung, indicating that MSCs restored lung injury by maintaining HGF levels in the lung, and the HGF expression is required for MSCs to protect the injured lung [105]. BM-derived progenitor cells enhance endothelial junction integrity and endothelial barrier function to prevent the increase in pulmonary microvascular permeability and edema formation in mice following LPS challenge by paracrine sphingosine-1-phosphate (S1P) release and activation of Rac-1 and Cdc42 [106]. Angiopoietin-1 (Ang-1) is a known endothelial survival and vascular stability factor that reduces endothelial permeability and suppresses leukocyte-endothelium interactions by modifying adhesion molecules and cell junctions of endothelial cells
[107]. MSCs promote therapeutic effects in injured mice by secreting Ang-1 [108]. Ang-1 was responsible for the beneficial effect of MSCs by preventing the formation of actin stress fiber and claudin 18 disorganization through $\mathrm{NF}-\kappa \mathrm{B}$ suppression [109]. MSCs directly reduced the nuclear translocation of NF- $\kappa \mathrm{B}$ in pigs with acute lung injury induced by intravenous oleic acid [110]. VEGF secreted by MSCs was important to maintain alveolar endothelium barrier [111].

\subsubsection{Anti-inflammatory cytokines}

One important pathogenesis of IPF is acute and/or chronic inflammation, which is also a key factor leading to the majority of IPF patients encountering recurrent lung injury [79]. Initially, IPF is known as an inflammatorydriven disease associated with the interactions of mononuclear cells, fibroblasts and cytokines. In BLMinduced PF models, the early acute inflammation is also important for the onset and progression of late PF [112]. Studies that used MSCs to treat inflammatory lung diseases reported that MSCs possess important antiinflammation effects, promoting lung tissue repair. For example, some researchers conducted phase I clinical trials to test the safety of MSCs on ARDS patients [113, 114]. Zheng et al. reported the safety of intravenous administration of hMSCs in 12 patients with ARDS in a double-blind randomized single-center trial [115]. MSC transplantation relieved pulmonary inflammation and damage in both intravenous LPS/zymosan-induced extrapulmonary ALI and intratracheal LPS-induced intrapulmonary ALI [116]. MSC transplantation combined with appropriate antimicrobial therapy also obviously decreased the mortality of septic mice through downregulation of inflammation and inflammationrelated genes and upregulation the expression of genes for enhancing bacterial clearance [117].

MSCs can secrete cytokine modulators and contribute to their anti-inflammatory effects [118]. In a comparative multiplex analysis, MSC-CM attenuated lung inflammation and promoted an anti-inflammatory M2 macrophage phenotype via insulin-like growth factor 1 (IGF-1) secretion in LPS-induced lung injury [119]. MSC$\mathrm{CM}$ attenuated the influx of inflammatory cells within the alveolar space while reversing histological evidence of lung fibrosis through the restoration of MSCs in the lungs accompanied by the inhibition of $\mathrm{T}$ cell proliferation [120]. BM-MSCs decreasing the inflammatory response and preventing the lungs from developing fibrosis are attributed to cell activation to secrete interleukin-1 receptor antagonist (IL-1ra) [121]. Yagi et al. found that hMSCs attenuated systemic inflammation in mice after i.p. injection of LPS through secreting soluble receptor-1 for TNF (sTNFR1), which binds to TNF- $\alpha$ and eliminates its action [122]. Lee et al. suggested that the alleviations of $\mathrm{PF}$ animals and IPF people after i.v. injection of MSCs in the tail were caused by MSCs activation to secrete TNF- $\alpha$ - 
stimulated gene/protein 6 (TSG-6), which is an significant anti-inflammatory gene and expressed in various kinds of cells $[47,123]$. However, hMSCs with TSG-6 siRNA were ineffective, and the advantages of hMSCs were greatly magnified through i.v. administration of recombinant human TSG-6 (rhTSG-6) [118, 124]. hMSCs and rhTSG-6 suppressed the Toll-like receptor $2 / \mathrm{NF}-\kappa \mathrm{B}$ signaling in the lung resident macrophages via directly interacting with CD44, then decreasing the produce of proinflammatory cytokines, TNF- $\alpha$, and IL- $1 \alpha$ [118, 125]. Jarvinen et al. demonstrated that BM-MSCs inhibited T cells activation by secreting prostaglandin E2 (PGE2), thereby stimulating alveolar macrophages secreting IL-10 [126]. PGE2 protects C57BL/6 mice lungs from BLM-induced $\mathrm{PF}$ and lung dysfunction [127]. The anti-inflammatory effects of PGE2 secreted by MSCs were dependent on the interaction of EP2 and EP4 receptors on macrophages [49, $118,128]$. Overexpression of EP2 receptor significantly enhanced MSCs migrating to injured lung tissue and further reduced LPS-induced pulmonary vascular permeability by decreasing the levels of proinflammatory cytokines [129]. MSCs transformed classically activated macrophages (M1MФ) into alternatively activated macrophages (M2M $)$, upregulating IL-10 and IL-6 [130132] (Figure 4).

However, MSCs ameliorated lung inflammation and fibrosis only when they were injected during the early stage of BLM-induced PF. If the fibrotic changes already exist, then MSCs do not have beneficial effects, and even worsen the lung injury and fibrosis. When MSCs were administered through tail vein on 7 day after BLM challenge, the inflammation had not been improved compared with the BLM model group [82]. It suggests MSCs play protective roles in the development of PF via influencing the early inflammatory process.

\section{Immunomodulation}

Multiple studies have determined that the production and deposition of extracellular matrix proteins in the process of PF are involved in various pathways, including growth factors, cytokines, and chemokines, associated with inflammation, cell transport, angiogenesis, and immunomodulation. Among these pathways, the role of humoral autoimmunity in IPF is an emerging subject of investigation. Autoantibodies are present in the plasma of $>80 \%$ of IPF patients [133]. Autoreactive T-cells against lung antigens have been detected in the same studies. IPF patients show peripheral wastage of NK cells and imbalance of the Treg/Th17 axis [134]. A total of $40 \%$ $60 \%$ of IPF patients may display an autoimmune response against type $\mathrm{V}$ collagen [col(V)] [135]. Anti-col(V) immunity is an important factor in IPF pathogenesis, and col(V)-induced tolerance downregulates TGF- $\beta$ related signaling pathways and eliminates BLM-induced fibrogenesis [136]. A phase 1 study has been conducted to test the safety and study the effective application of IW001 in the treatment of $\operatorname{col}(\mathrm{V})$ antibody-positive IPF patients [137]. Patients with IPF often have elevated serum levels of SP-A and SP-D, which possess significant innate immune function because of the capabilities to give rise to both pro-inflammatory and anti-inflammatory responses [138-140]. SP-D deficiency increased the numbers of macrophages and fibrocytes in lung tissues, the expression of profibrotic cytokines (TGF- $\beta 1$ and PDGF-AA) in BLMinduced PF. And intratracheal injection of SP-D relieved BLM-induced PF in SP-D ${ }^{-/}$mice [141]. These studies support the hypothesis that autoimmune response to autoantibodies may play a vital role in the progression of disease for patients with IPF.

A number of studies have shown that MSC has a strong immunosuppressive effect through producing the abovementioned paracrine factors. However, the mechanisms by which MSCs mediate the immunosuppression are yet to be determined. MSCs produced a large number of chemokines (CXCR3 and CCR5 ligand chemokines) and adhesion molecules, including intercellular adhesion molecule (ICAM)-1 and vascular cell adhesion molecule (VCAM)-1[142, 143]. Then, immune cells aggregated near MSCs, which secreted high concentrations of nitric oxide (NO) and indoleamine2,3-dioxygenase (IDO) then suppressed $\mathrm{T}$ cells proliferation [144]. High concentrations of NO inhibited immune responses by suppressing phosphorylation of signal transducer and activator of transcription (STAT) 5 and promoting apoptosis of T cells [145]. Furthermore, MSCs secreted IL-6 in vitro, then induced B lymphocytes to produce IgG [146]. A research suggested that the IL6-dependent PGE2 production played a crucial role in the beneficial therapy of MSCs in experimental mouse arthritis model [147]. However, the expression of cytokine and chemokine receptors was decreased in aged BMMSCs and their protective roles were compromised due to impaired migration and anti-inflammatory response [148]. This result may be because aging can lead to significant alterations in extracellular matrix composition, inflammatory mediators, and chemokines and increased susceptibility to oxidative stress.

Interestingly, research has shown that MSCs also can secrete TGF- $\beta$, which is a key profibrotic protein [149]. This MSC mechanism may explain why they aggravate BLM-induced lung fibrosis when administered to mice during the late fibrotic phase. This result is seemingly contradictory to the antifibrotic effects of MSCs. However, Liu et al. found that the supernatant derived from human BM-MSCs isolated from normal individuals expressed a high level of TGF- $\beta 1$ and had a better therapeutic effect in reducing the mortality, inflammation, and fibrosis than that from MSCs derived from umbilical cord which secreted a low level of TGF- $\beta 1$ [150]. In that study, TGF- $\beta 1$ hypersecretion in BM-MSCs activated IL-6/ STAT3 signal pathway, then promoting Tregs proliferation and production of antifibrotic chemokine IFN- $\gamma$-inducible 
protein 10 . This study implies that TGF- $\beta$ secreted by MSCs can modulate immune responses to ameliorate inflammation and fibrosis, and this mechanism may be important to MSC resistance to PF. Moreover, TGF- $\beta 1$ can regulate immune homeostasis. $\mathrm{T}$ cells were abnormally activated and some proinflammatory cytokines were significantly increased in TGF- $\beta 1$ deficiency mice [151]. IL-4 and/or IL-13 activated the STAT6 signal in BMMSCs, leading to an increase in TGF- $\beta$ production, which was useful alone or in combination with regulatory $\mathrm{T}$ cells [149]. In the presence of pro-inflammatory cytokines such as IL-1 $\beta$, IL-6, and IL-23, MSCs retained the ability to inhibit allogeneic $\mathrm{T}$ cell proliferation and secreted high levels of TGF- $\beta$ and low levels of IL-4 [152]. Therefore, the timing of MSC administration is crucial to determine whether the cells will eventually have a favorable or adverse impact on PF development. The greatest benefit of MSCs occurs in the early inflammatory stages of PF.

\section{Extracellular vesicles}

Extracellular vesicles (EVs) are diminutive and orbicular membrane segments, including exosomes, microvesicles (MVs), and apoptotic bodies, as described by the recommendations of the International Society for Extracellular Vesicles [153]. EVs can be produced by various type cells as well as separated from body fluids in vivo, involving in cell-to-cell communication and mediating the phenotypic changes of receptor cells [154, 155].

Notably, a number of studies showed that the paracrine benefits of MSCs were also mediated by EVs contained in MSC-CM except the abovementioned soluble factors [97]. Therefore, some researchers proposed that MSC-CM and/or MSC EVs can be used as treatment for acute lung injury and other inflammatory lung diseases. Recently, a research group found that MSCs secreted three types of EVs [156]. MSC-derived EVs also expressed MSC phenotypic markers, such as CD29, CD73, CD44, and CD105, and can be identified through conventional flow cytometry [157]. The microvesicles isolated from MSC-CM reduced the total cell count in BALF, alveolar macrophages ratio, inflammation, and fibrosis [158].

MSC-derived EVs can be an important tool for the clinical benefit of MSC treatment and may reduce risks associated with engraftment of MSCs [159]. Recently, Pachhler et al. proposed a good manufacturing practicegrade standard protocol for exclusively human MSCderived EVs [160]. The characterization and establishment of MSC-derived EVs will help identify active components in therapeutic EVs for future clinical applications.

MSC-derived extracellular vesicles may be an important tool for the clinical benefit of MSC treatment and may reduce the risk associated with transplanting MSCs.

\section{Signal molecules regulated by MSCs}

MSCs elicit their beneficial effects not only via these mechanisms but also via regulation of some signal molecules to improve the endogenous capability of lungs to resist damage. MSCs reduce the expression of matrix metalloproteinase (MMP9), tissue inhibitor of metalloproteinase- $1, \gamma$-interferon, and TGF- $\beta 1$ to suppress lung inflammation and fibrosis [161]. MSCs also alleviate pulmonary damage and mortality in association with a reduce in macrophage inflammatory protein-2 and TNF- $\alpha$ levels in BALF and high levels of IL-10 in plasma and BALF [162]. Ni et al. suggested that BMMSCs significantly ameliorate the BLM-induced PF by increasing the gene expression levels of NAD(P) $\mathrm{H}$ : quinine oxidoreductase 1 , gamma-glutamylcysteine synthetase, heme oxygenase-1, and nuclear factor erythroid 2-related factor 2 [163]. These results indicate that MSCs can promote lung resistance against inflammation and oxidative stress by regulating antiinflammatory and antioxidant factors.

Scientists are also actively looking for the endogenous mediators induced by MSCs for pulmonary homeostasis. The increasing expression of FoxM1 induced by BMPC treatment is a critical endogenous mediator against inflammatory lung injury [164]. Moreover, The endothelial FoxM1 is required for paracrine released by MSCs in S1P-mediated enhancement of endothelial barrier function [164]. MSCs were susceptible to oxidative stress after decreasing stanniocalcin, whereas stanniocalcin overexpression in MSCs alleviated oxidative stress [165]. STC1 plasmid transfected to MSCs enhanced the capability of MSCs to ameliorate the fibrosis by reducing oxidative stress, endoplasmic reticulum stress, and TGF- $\beta 1$ production in AECs [165]. MSCs expressing stanniocalcin 2 (STC2) exhibit increased cell viability, improved cell survival, and increased pluripotency and self-renewal marker expression by activating p-AKT and p-ERK1/2 signal pathways under oxidative conditions [166]. Ahmad et al. proved that MSCs overexpressing the mitochondrial transport protein Miro1 promoted mitochondrial transfer from MSCs to damaged epithelial cells and rescued the epithelial injury [167]. These results suggest that FoxM1, stanniocalcin, and Miro1 may be essential factors that regulate the endogenous injury repair and mediate the effects of MSCs to ameliorate lung injury and PF.

\section{CONCLUSION AND PERSPECTIVES}

In summary, MSC administration can be an effective therapy to alleviate BLM-induced lung injury and fibrosis. The mechanisms involve multiple biological effects of MSCs, including homing, differentiation, secretome, and promotion of lung endogenous antidamage ability. 
However, a large proportion of studies have explore the early inflammatory stage rather than the late fibrotic stage. This is a major limitation that MSC administration is only used as a preventive measure but not as a treatment modality. Therefore, the timing of MSC administration is crucial. Some controversies on the effectiveness and safety of MSC administration for IPF have been presented. Thus, further research on the mobilization of endogenous MSCs from BM and its mechanisms should be performed. Recently, MicroRNAs are found to participate in IPF pathogenesis [168]. However, the role of MicroRNAs in improving the beneficial effects of MSCs is unknown. Hence, further research and clinical trials should be conducted.

\section{ACKNOWLEDGMENTS}

This work was supported by the National Natural Science Foundation of China $(81570065,81270121)$, the Fundamental Research Funds for the Central Universities of Central South University (2016zzts 115), the Open-End Fund for the Valuable and Precision Instrument of Central South University (CSUZC201740), and Innovation Fund for Institution of Higher Education of Hunan Province grant number (11K076).

\section{CONFLICTS OF INTERESTS}

The authors declared no competing financial interests exist.

\section{REFERENCES}

1. Liu YM, Nepali K, Liou JP. Idiopathic Pulmonary Fibrosis: Current Status, Recent Progress, and Emerging Targets. J Med Chem. 2017; 60:527-53.

2. Padilla M. Idiopathic pulmonary fibrosis: the role of pathobiology in making a definitive diagnosis. Am J Manag Care. 2015 (Suppl); 21:s276-83.

3. Loomis-King H, Flaherty KR, Moore BB. Pathogenesis, current treatments and future directions for idiopathic pulmonary fibrosis. Curr Opin Pharmacol. 2013; 13:37785.

4. Álvarez D, Levine M, Rojas M. Regenerative medicine in the treatment of idiopathic pulmonary fibrosis: current position. Stem Cells Cloning. 2015; 8:61-65.

5. Tzouvelekis A, Bonella F, Spagnolo P. Update on therapeutic management of idiopathic pulmonary fibrosis. Ther Clin Risk Manag. 2015; 11:359-70.

6. Navaratnam V, Fleming KM, West J, Smith CJ, Jenkins RG, Fogarty A, Hubbard RB. The rising incidence of idiopathic pulmonary fibrosis in the U.K. Thorax. 2011; 66:462-67.

7. Raghu G, Rochwerg B, Zhang Y, Garcia CA, Azuma A, Behr J, Brozek JL, Collard HR, Cunningham W, Homma
S, Johkoh T, Martinez FJ, Myers J, et al, and American Thoracic Society, and European Respiratory society, and Japanese Respiratory Society, and Latin American Thoracic Association. An official ATS/ERS/JRS/ALAT clinical practice guideline: treatment of idiopathic pulmonary fibrosis. An update of the 2011 clinical practice guideline. Am J Respir Crit Care Med. 2015; 192:e3-19.

8. Hagmeyer L, Treml M, Priegnitz C, Randerath WJ. Successful Concomitant Therapy with Pirfenidone and Nintedanib in Idiopathic Pulmonary Fibrosis: A Case Report. Respiration. 2016; 91:327-32.

9. Tzouvelekis A, Antoniadis A, Bouros D. Stem cell therapy in pulmonary fibrosis. Curr Opin Pulm Med. 2011; 17:36873.

10. Antunes MA, Laffey JG, Pelosi P, Rocco PR. Mesenchymal stem cell trials for pulmonary diseases. J Cell Biochem. 2014; 115:1023-32.

11. Sinclair K, Yerkovich ST, Chambers DC. Mesenchymal stem cells and the lung. Respirology. 2013; 18:397-411.

12. Qin ZH, Xu JF, Qu JM, Zhang J, Sai Y, Chen CM, Wu L, $\mathrm{Yu}$ L. Intrapleural delivery of MSCs attenuates acute lung injury by paracrine/endocrine mechanism. J Cell Mol Med. 2012; 16:2745-53.

13. Bagnato G, Harari S. Cellular interactions in the pathogenesis of interstitial lung diseases. Eur Respir Rev. 2015; 24:102-14.

14. Chilosi M, Poletti V, Zamò A, Lestani M, Montagna L, Piccoli P, Pedron S, Bertaso M, Scarpa A, Murer B, Cancellieri A, Maestro R, Semenzato G, Doglioni C. Aberrant Wnt/beta-catenin pathway activation in idiopathic pulmonary fibrosis. Am J Pathol. 2003; 162:1495-502.

15. Hinz B, Phan SH, Thannickal VJ, Galli A, Bochaton-Piallat ML, Gabbiani G. The myofibroblast: one function, multiple origins. Am J Pathol. 2007; 170:1807-16.

16. Kim KK, Kugler MC, Wolters PJ, Robillard L, Galvez MG, Brumwell AN, Sheppard D, Chapman HA. Alveolar epithelial cell mesenchymal transition develops in vivo during pulmonary fibrosis and is regulated by the extracellular matrix. Proc Natl Acad Sci USA. 2006; 103:13180-85.

17. Willis BC, Liebler JM, Luby-Phelps K, Nicholson AG, Crandall ED, du Bois RM, Borok Z. Induction of epithelial-mesenchymal transition in alveolar epithelial cells by transforming growth factor-beta1: potential role in idiopathic pulmonary fibrosis. Am J Pathol. 2005; 166:1321-32.

18. Thiery JP, Sleeman JP. Complex networks orchestrate epithelial-mesenchymal transitions. Nat Rev Mol Cell Biol. 2006; 7:131-42.

19. Marmai C, Sutherland RE, Kim KK, Dolganov GM, Fang X, Kim SS, Jiang S, Golden JA, Hoopes CW, Matthay MA, Chapman HA, Wolters PJ. Alveolar epithelial cells express mesenchymal proteins in patients with idiopathic pulmonary fibrosis. Am J Physiol Lung Cell Mol Physiol. 
2011; 301:L71-78.

20. Iwano M, Plieth D, Danoff TM, Xue C, Okada H, Neilson EG. Evidence that fibroblasts derive from epithelium during tissue fibrosis. J Clin Invest. 2002; 110:341-50.

21. Xu J, Lamouille S, Derynck R. TGF- $\beta$-induced epithelial to mesenchymal transition. Cell Res. 2009; 19:156-72.

22. Kasai H, Allen JT, Mason RM, Kamimura T, Zhang Z. TGF-beta1 induces human alveolar epithelial to mesenchymal cell transition (EMT). Respir Res. 2005; 6:56.

23. Kage H, Borok Z. EMT and interstitial lung disease: a mysterious relationship. Curr Opin Pulm Med. 2012; 18:517-23.

24. Franks TJ, Colby TV, Travis WD, Tuder RM, Reynolds HY, Brody AR, Cardoso WV, Crystal RG, Drake CJ, Engelhardt J, Frid M, Herzog E, Mason R, et al. Resident cellular components of the human lung: current knowledge and goals for research on cell phenotyping and function. Proc Am Thorac Soc. 2008; 5:763-66.

25. Frid MG, Kale VA, Stenmark KR. Mature vascular endothelium can give rise to smooth muscle cells via endothelial-mesenchymal transdifferentiation: in vitro analysis. Circ Res. 2002; 90:1189-96.

26. Arciniegas E, Frid MG, Douglas IS, Stenmark KR. Perspectives on endothelial-to-mesenchymal transition: potential contribution to vascular remodeling in chronic pulmonary hypertension. Am J Physiol Lung Cell Mol Physiol. 2007; 293:L1-8.

27. Hashimoto N, Phan SH, Imaizumi K, Matsuo M, Nakashima H, Kawabe T, Shimokata K, Hasegawa Y. Endothelialmesenchymal transition in bleomycin-induced pulmonary fibrosis. Am J Respir Cell Mol Biol. 2010; 43:161-72.

28. Phillips RJ, Burdick MD, Hong K, Lutz MA, Murray LA, Xue YY, Belperio JA, Keane MP, Strieter RM. Circulating fibrocytes traffic to the lungs in response to CXCL12 and mediate fibrosis. J Clin Invest. 2004; 114:438-46.

29. Hashimoto N, Jin H, Liu T, Chensue SW, Phan SH. Bone marrow-derived progenitor cells in pulmonary fibrosis. J Clin Invest. 2004; 113:243-52.

30. Mehrad B, Burdick MD, Zisman DA, Keane MP, Belperio JA, Strieter RM. Circulating peripheral blood fibrocytes in human fibrotic interstitial lung disease. Biochem Biophys Res Commun. 2007; 353:104-08.

31. Andersson-Sjöland A, de Alba CG, Nihlberg K, Becerril C, Ramírez R, Pardo A, Westergren-Thorsson G, Selman M. Fibrocytes are a potential source of lung fibroblasts in idiopathic pulmonary fibrosis. Int $\mathrm{J}$ Biochem Cell Biol. 2008; 40:2129-40.

32. Moeller A, Gilpin SE, Ask K, Cox G, Cook D, Gauldie J, Margetts PJ, Farkas L, Dobranowski J, Boylan C, O’Byrne PM, Strieter RM, Kolb M. Circulating fibrocytes are an indicator of poor prognosis in idiopathic pulmonary fibrosis. Am J Respir Crit Care Med. 2009; 179:588-94.

33. Borie R, Quesnel C, Phin S, Debray MP, Marchal-Somme J, Tiev K, Bonay M, Fabre A, Soler P, Dehoux M, Crestani
B. Detection of alveolar fibrocytes in idiopathic pulmonary fibrosis and systemic sclerosis. PLoS One. 2013; 8:e53736.

34. Song JS, Kang CM, Kang HH, Yoon HK, Kim YK, Kim KH, Moon HS, Park SH. Inhibitory effect of CXC chemokine receptor 4 antagonist AMD3100 on bleomycin induced murine pulmonary fibrosis. Exp Mol Med. 2010; 42:465-72.

35. Mehrad B, Burdick MD, Strieter RM. Fibrocyte CXCR4 regulation as a therapeutic target in pulmonary fibrosis. Int J Biochem Cell Biol. 2009; 41:1708-18.

36. Xu J, Mora A, Shim H, Stecenko A, Brigham KL, Rojas $\mathrm{M}$. Role of the SDF-1/CXCR4 axis in the pathogenesis of lung injury and fibrosis. Am J Respir Cell Mol Biol. 2007; 37:291-99.

37. Moore BB, Kolodsick JE, Thannickal VJ, Cooke K, Moore TA, Hogaboam C, Wilke CA, Toews GB. CCR2-mediated recruitment of fibrocytes to the alveolar space after fibrotic injury. Am J Pathol. 2005; 166:675-84.

38. Moore BB, Murray L, Das A, Wilke CA, Herrygers AB, Toews GB. The role of CCL12 in the recruitment of fibrocytes and lung fibrosis. Am J Respir Cell Mol Biol. 2006; 35:175-81.

39. Ishida $\mathrm{Y}$, Kimura A, Kondo T, Hayashi T, Ueno M, Takakura N, Matsushima K, Mukaida N. Essential roles of the $\mathrm{CC}$ chemokine ligand $3-\mathrm{CC}$ chemokine receptor 5 axis in bleomycin-induced pulmonary fibrosis through regulation of macrophage and fibrocyte infiltration. Am J Pathol. 2007; 170:843-54.

40. Friedenstein AJ, Petrakova KV, Kurolesova AI, Frolova GP. Heterotopic of bone marrow. Analysis of precursor cells for osteogenic and hematopoietic tissues. Transplantation. 1968; 6:230-247.

41. Okamoto R, Yajima T, Yamazaki M, Kanai T, Mukai M, Okamoto S, Ikeda Y, Hibi T, Inazawa J, Watanabe M. Damaged epithelia regenerated by bone marrow-derived cells in the human gastrointestinal tract. Nat Med. 2002; 8:1011-17.

42. Dominici M, Le Blanc K, Mueller I, Slaper-Cortenbach I, Marini F, Krause D, Deans R, Keating A, Prockop D, Horwitz E. Minimal criteria for defining multipotent mesenchymal stromal cells. The International Society for Cellular Therapy position statement. Cytotherapy. 2006; 8:315-17.

43. Xu S, De Becker A, Van Camp B, Vanderkerken K, Van Riet I. An improved harvest and in vitro expansion protocol for murine bone marrow-derived mesenchymal stem cells. J Biomed Biotechnol. 2010; 2010:105940.

44. McBride C, Gaupp D, Phinney DG. Quantifying levels of transplanted murine and human mesenchymal stem cells in vivo by real-time PCR. Cytotherapy. 2003; 5:7-18.

45. Huleihel L, Levine M, Rojas M. The potential of cell-based therapy in lung diseases. Expert Opin Biol Ther. 2013; 13:1429-40.

46. Xu YQ, Liu ZC. Therapeutic potential of adult bone marrow 
stem cells in liver disease and delivery approaches. Stem Cell Rev. 2008; 4:101-12.

47. Lee RH, Pulin AA, Seo MJ, Kota DJ, Ylostalo J, Larson BL, Semprun-Prieto L, Delafontaine P, Prockop DJ. Intravenous hMSCs improve myocardial infarction in mice because cells embolized in lung are activated to secrete the anti-inflammatory protein TSG-6. Cell Stem Cell. 2009; 5:54-63.

48. Lee RH, Seo MJ, Reger RL, Spees JL, Pulin AA, Olson SD, Prockop DJ. Multipotent stromal cells from human marrow home to and promote repair of pancreatic islets and renal glomeruli in diabetic NOD/scid mice. Proc Natl Acad Sci USA. 2006; 103:17438-43.

49. Németh K, Leelahavanichkul A, Yuen PS, Mayer B, Parmelee A, Doi K, Robey PG, Leelahavanichkul K, Koller BH, Brown JM, Hu X, Jelinek I, Star RA, Mezey E. Bone marrow stromal cells attenuate sepsis via prostaglandin $\mathrm{E}(2)$-dependent reprogramming of host macrophages to increase their interleukin-10 production. Nat Med. 2009; 15:42-49.

50. Tögel F, Hu Z, Weiss K, Isaac J, Lange C, Westenfelder C. Administered mesenchymal stem cells protect against ischemic acute renal failure through differentiationindependent mechanisms. Am J Physiol Renal Physiol. 2005; 289:F31-42.

51. Horwitz EM, Gordon PL, Koo WK, Marx JC, Neel MD, McNall RY, Muul L, Hofmann T. Isolated allogeneic bone marrow-derived mesenchymal cells engraft and stimulate growth in children with osteogenesis imperfecta: implications for cell therapy of bone. Proc Natl Acad Sci USA. 2002; 99:8932-37.

52. Sherman LS, Shaker M, Mariotti V, Rameshwar P. Mesenchymal stromal/stem cells in drug therapy: new perspective. Cytotherapy. 2017; 19:19-27.

53. Enzmann V, Lecaudé S, Kruschinski A, Vater A. CXCL12/ SDF-1-dependent retinal migration of endogenous bone marrow-derived stem cells improves visual function after pharmacologically induced retinal degeneration. Stem Cell Rev. 2017; 13:278-86.

54. Rennert RC, Sorkin M, Garg RK, Gurtner GC. Stem cell recruitment after injury: lessons for regenerative medicine. Regen Med. 2012; 7:833-50.

55. Frenette PS, Pinho S, Lucas D, Scheiermann C. Mesenchymal stem cell: keystone of the hematopoietic stem cell niche and a stepping-stone for regenerative medicine. Annu Rev Immunol. 2013; 31:285-316.

56. Deng J, Zou ZM, Zhou TL, Su YP, Ai GP, Wang JP, Xu $\mathrm{H}$, Dong SW. Bone marrow mesenchymal stem cells can be mobilized into peripheral blood by G-CSF in vivo and integrate into traumatically injured cerebral tissue. Neurol Sci. 2011; 32:641-51.

57. Park D, Spencer JA, Koh BI, Kobayashi T, Fujisaki J, Clemens TL, Lin CP, Kronenberg HM, Scadden DT. Endogenous bone marrow MSCs are dynamic, fate-restricted participants in bone maintenance and regeneration. Cell Stem Cell. 2012; 10:259-72.

58. Borghesi A, Massa M, Campanelli R, Bollani L, Tzialla C, Figar TA, Ferrari G, Bonetti E, Chiesa G, de Silvestri A, Spinillo A, Rosti V, Stronati M. Circulating endothelial progenitor cells in preterm infants with bronchopulmonary dysplasia. Am J Respir Crit Care Med. 2009; 180:540-46.

59. Agostini C. Stem cell therapy for chronic lung diseases: hope and reality. Respir Med. 2010 (Suppl 1); 104:S86-91.

60. Rojas M, Xu J, Woods CR, Mora AL, Spears W, Roman J, Brigham KL. Bone marrow-derived mesenchymal stem cells in repair of the injured lung. Am J Respir Cell Mol Biol. 2005; 33:145-52.

61. Wang Q, Zhu H, Zhou WG, Guo XC, Wu MJ, Xu ZY, Jiang JF, Shen C, Liu HQ. N-acetylcysteine-pretreated human embryonic mesenchymal stem cell administration protects against bleomycin-induced lung injury. Am J Med Sci. 2013; 346:113-22.

62. Lan YW, Theng SM, Huang TT, Choo KB, Chen CM, Kuo HP, Chong KY. Oncostatin M-preconditioned mesenchymal stem cells alleviate bleomycin-induced pulmonary fibrosis through paracrine effects of the hepatocyte growth factor. Stem Cells Transl Med. 2017; 6:1006-17.

63. Petit I, Szyper-Kravitz M, Nagler A, Lahav M, Peled A, Habler L, Ponomaryov T, Taichman RS, ArenzanaSeisdedos F, Fujii N, Sandbank J, Zipori D, Lapidot T. G-CSF induces stem cell mobilization by decreasing bone marrow SDF-1 and up-regulating CXCR4. Nat Immunol. 2002; 3:687-94.

64. Urdzíková L, Jendelová P, Glogarová K, Burian M, Hájek M, Syková E. Transplantation of bone marrow stem cells as well as mobilization by granulocyte-colony stimulating factor promotes recovery after spinal cord injury in rats. $\mathrm{J}$ Neurotrauma. 2006; 23:1379-91.

65. Zhang F, Zhang L, Jiang HS, Chen XY, Zhang Y, Li HP, Zhang RX, Zheng H, Chu JX, Chen XJ. Mobilization of bone marrow cells by CSF3 protects mice from bleomycininduced lung injury. Respiration. 2011; 82:358-68.

66. Lee HJ, Choi CW, Kim EK, Kim HS, Kim BI, Choi JH. Granulocyte colony-stimulating factor reduces hyperoxiainduced alveolarization inhibition by increasing angiogenic factors. Neonatology. 2012; 101:278-84.

67. Azoulay E, Herigault S, Levame M, Brochard L, Schlemmer B, Harf A, Delclaux C. Effect of granulocyte colony-stimulating factor on bleomycin-induced acute lung injury and pulmonary fibrosis. Crit Care Med. 2003; 31:1442-48.

68. Ziora D, Jastrzębski D, Adamek M, Czuba Z, Kozielski JJ, Grzanka A, Kasperska-Zajac A. Circulating concentration of markers of angiogenic activity in patients with sarcoidosis and idiopathic pulmonary fibrosis. BMC Pulm Med. 2015; 15:113.

69. Dygai AM, Skurikhin EG, Andreeva TV, Ermolaeva LA, Khmelevskaya ES, Pershina OV, Krupin VA, Reztsova 
AM, Stepanova IE, Goldberg VE. Reactions of the blood system and stem cells in bleomycin-induced model of lung fibrosis. Bull Exp Biol Med. 2011; 152:173-76.

70. Silva JD, Paredes BD, Araújo IM, Lopes-Pacheco M, Oliveira MV, Suhett GD, Faccioli LA, Assis E, CastroFaria-Neto HC, Goldenberg RC, Capelozzi VL, Morales MM, Pelosi P, et al. Effects of bone marrow-derived mononuclear cells from healthy or acute respiratory distress syndrome donors on recipient lung-injured mice. Crit Care Med. 2014; 42:e510-24.

71. Antoniou KM, Papadaki HA, Soufla G, Kastrinaki MC, Damianaki A, Koutala H, Spandidos DA, Siafakas NM. Investigation of bone marrow mesenchymal stem cells (BM MSCs) involvement in Idiopathic Pulmonary Fibrosis (IPF). Respir Med. 2010; 104:1535-42.

72. Srour N, Thébaud B. Mesenchymal Stromal Cells in Animal Bleomycin Pulmonary Fibrosis Models: A Systematic Review. Stem Cells Transl Med. 2015; 4:1500-10.

73. Ortiz LA, Gambelli F, McBride C, Gaupp D, Baddoo M, Kaminski N, Phinney DG. Mesenchymal stem cell engraftment in lung is enhanced in response to bleomycin exposure and ameliorates its fibrotic effects. Proc Natl Acad Sci USA. 2003; 100:8407-11.

74. Choi M, Ban T, Rhim T. Therapeutic use of stem cell transplantation for cell replacement or cytoprotective effect of microvesicle released from mesenchymal stem cell. Mol Cells. 2014; 37:133-39.

75. Lee SH, Jang AS, Kim YE, Cha JY, Kim TH, Jung S, Park SK, Lee YK, Won JH, Kim YH, Park CS. Modulation of cytokine and nitric oxide by mesenchymal stem cell transfer in lung injury/fibrosis. Respir Res. 2010; 11:16.

76. Zhao F, Zhang YF, Liu YG, Zhou JJ, Li ZK, Wu CG, Qi HW. Therapeutic effects of bone marrow-derived mesenchymal stem cells engraftment on bleomycin-induced lung injury in rats. Transplant Proc. 2008; 40:1700-05.

77. $\mathrm{Xu} \mathrm{J,} \mathrm{Li} \mathrm{L,} \mathrm{Xiong} \mathrm{J,} \mathrm{Zheng} \mathrm{Y,} \mathrm{Ye} \mathrm{Q,} \mathrm{Li} \mathrm{Y.}$ Cyclophosphamide Combined with Bone Marrow Mesenchymal Stromal Cells Protects against Bleomycininduced Lung Fibrosis in Mice. Ann Clin Lab Sci. 2015; 45:292-300.

78. Glassberg MK, Minkiewicz J, Toonkel RL, Simonet ES, Rubio GA, DiFede D, Shafazand S, Khan A, Pujol MV, LaRussa VF, Lancaster LH, Rosen GD, Fishman J, et al. Allogeneic human mesenchymal stem cells in patients with idiopathic pulmonary fibrosis via intravenous delivery (AETHER): a phase I safety clinical trial. Chest. 2017; 151:971-81.

79. Wallace WA, Fitch PM, Simpson AJ, Howie SE. Inflammation-associated remodelling and fibrosis in the lung - a process and an end point. Int J Exp Pathol. 2007; 88:103-10.

80. Adamson IY, Young L, Bowden DH. Relationship of alveolar epithelial injury and repair to the induction of pulmonary fibrosis. Am J Pathol. 1988; 130:377-83.
81. Ricciardi M, Midolo M, Bassi G, Malpeli G, Bifari F, Chilosi M, Zanotto M, Carusone R, Zanoncello J, Pizzolo G, Krampera M. Comparison between bone marrow mesenchymal stromal cells (BM-MSC) and lung mesenchymal stromal cells (Lung-MSC) for epithelial regeneration. Blood. 2013; 122:5414.

82. Akram KM, Samad S, Spiteri MA, Forsyth NR. Mesenchymal stem cells promote alveolar epithelial cell wound repair in vitro through distinct migratory and paracrine mechanisms. Respir Res. 2013; 14:9.

83. Marquez-Curtis LA, Janowska-Wieczorek A. Enhancing the migration ability of mesenchymal stromal cells by targeting the SDF-1/CXCR4 axis. BioMed Res Int. 2013; 2013:561098.

84. Yang IV, Burch LH, Steele MP, Savov JD, Hollingsworth JW, McElvania-Tekippe E, Berman KG, Speer MC, Sporn TA, Brown KK, Schwarz MI, Schwartz DA. Gene expression profiling of familial and sporadic interstitial pneumonia. Am J Respir Crit Care Med. 2007; 175:45-54.

85. Ringe J, Strassburg S, Neumann K, Endres M, Notter M, Burmester GR, Kaps C, Sittinger M. Towards in situ tissue repair: human mesenchymal stem cells express chemokine receptors CXCR1, CXCR2 and CCR2, and migrate upon stimulation with CXCL8 but not CCL2. J Cell Biochem. 2007; 101:135-46.

86. Liu AR, Liu L, Chen S, Yang Y, Zhao HJ, Liu L, Guo FM, Lu XM, Qiu HB. Activation of canonical wnt pathway promotes differentiation of mouse bone marrowderived MSCs into type II alveolar epithelial cells, confers resistance to oxidative stress, and promotes their migration to injured lung tissue in vitro. J Cell Physiol. 2013; 228:1270-83.

87. Cai SX, Liu AR, Chen S, He HL, Chen QH, Xu JY, Pan C, Yang Y, Guo FM, Huang YZ, Liu L, Qiu HB. Activation of Wnt/ $\beta$-catenin signalling promotes mesenchymal stem cells to repair injured alveolar epithelium induced by lipopolysaccharide in mice. Stem Cell Res Ther. 2015; 6:65.

88. Liu A, Chen S, Cai S, Dong L, Liu L, Yang Y, Guo F, Lu X, He H, Chen Q, Hu S, Qiu H. Wnt5a through noncanonical $\mathrm{Wnt} / \mathrm{JNK}$ or $\mathrm{Wnt} / \mathrm{PKC}$ signaling contributes to the differentiation of mesenchymal stem cells into type II alveolar epithelial cells in vitro. PLoS One. 2014; 9:e90229.

89. Ling L, Nurcombe V, Cool SM. Wnt signaling controls the fate of mesenchymal stem cells. Gene. 2009; 433:1-7.

90. Sun Z, Gong X, Zhu H, Wang C, Xu X, Cui D, Qian W, Han $X$. Inhibition of $W n t / \beta$-catenin signaling promotes engraftment of mesenchymal stem cells to repair lung injury. J Cell Physiol. 2014; 229:213-24.

91. Tang N, Zhao Y, Feng R, Liu Y, Wang S, Wei W, Ding Q, An MS, Wen J, Li L. Lysophosphatidic acid accelerates lung fibrosis by inducing differentiation of mesenchymal stem cells into myofibroblasts. J Cell Mol Med. 2014; 18:156-69.

92. Mora AL, Rojas M. Aging and lung injury repair: a role 
for bone marrow derived mesenchymal stem cells. J Cell Biochem. 2008; 105:641-47.

93. Skurikhin EG, Khmelevskaya ES, Pershina OV, Ermakova NN, Krupin VA, Reztsova AM, Ermolaeva LA, Yakushina VD, Stepanova IE, Reztsova VM, Cherdyntseva NV, Stakheeva MN, Dygai AM. Differentiation of mesenchymal multipotent stromal cells of the lungs in pneumofibrosis. Bull Exp Biol Med. 2013; 154:537-43.

94. Minguell JJ, Allers C, Lasala GP. Mesenchymal stem cells and the treatment of conditions and diseases: the less glittering side of a conspicuous stem cell for basic research. Stem Cells Dev. 2013; 22:193-203.

95. Galderisi U, Giordano A. The gap between the physiological and therapeutic roles of mesenchymal stem cells. Med Res Rev. 2014; 34:1100-26.

96. Shen Q, Chen B, Xiao Z, Zhao L, Xu X, Wan X, Jin M, Dai J, Dai H. Paracrine factors from mesenchymal stem cells attenuate epithelial injury and lung fibrosis. Mol Med Rep. 2015; 11:2831-37.

97. Monsel A, Zhu YG, Gudapati V, Lim H, Lee JW. Mesenchymal stem cell derived secretome and extracellular vesicles for acute lung injury and other inflammatory lung diseases. Expert Opin Biol Ther. 2016; 16:859-71.

98. Caplan AI, Correa D. The MSC: an injury drugstore. Cell Stem Cell. 2011; 9:11-15.

99. Kusuma GD, Carthew J, Lim R, Frith JE. Effect of the microenvironment on mesenchymal stem cells paracrine signalling: opportunities to engineer the therapeutic effect. Stem Cells Dev. 2017; 26:617-31.

100. Lavoie JR, Rosu-Myles M. Uncovering the secretes of mesenchymal stem cells. Biochimie. 2013; 95:2212-21.

101. Lee JW, Fang X, Gupta N, Serikov V, Matthay MA. Allogeneic human mesenchymal stem cells for treatment of E. coli endotoxin-induced acute lung injury in the ex vivo perfused human lung. Proc Natl Acad Sci USA. 2009; 106:16357-62.

102. Yi ES, Salgado M, Williams S, Kim SJ, Masliah E, Yin S, Ulich TR. Keratinocyte growth factor decreases pulmonary edema, transforming growth factor-beta and platelet-derived growth factor-BB expression, and alveolar type II cell loss in bleomycin-induced lung injury. Inflammation. 1998; 22:315-25.

103. Aguilar S, Scotton CJ, McNulty K, Nye E, Stamp G, Laurent G, Bonnet D, Janes SM. Bone marrow stem cells expressing keratinocyte growth factor via an inducible lentivirus protects against bleomycin-induced pulmonary fibrosis. PLoS One. 2009; 4:e8013.

104. Lan YW, Choo KB, Chen CM, Hung TH, Chen YB, Hsieh CH, Kuo HP, Chong KY. Hypoxia-preconditioned mesenchymal stem cells attenuate bleomycin-induced pulmonary fibrosis. Stem Cell Res Ther. 2015; 6:97.

105. Hu S, Li J, Xu X, Liu A, He H, Xu J, Chen Q, Liu S, Liu L, Qiu H, Yang Y. The hepatocyte growth factor-expressing character is required for mesenchymal stem cells to protect the lung injured by lipopolysaccharide in vivo. Stem Cell Res Ther. 2016; 7:66.

106. Zhao YD, Ohkawara H, Rehman J, Wary KK, Vogel SM, Minshall RD, Zhao YY, Malik AB. Bone marrow progenitor cells induce endothelial adherens junction integrity by sphingosine-1-phosphate-mediated Rac1 and Cdc42 signaling. Circ Res. 2009; 105:696-704, 8, 704.

107. Pizurki L, Zhou Z, Glynos K, Roussos C, Papapetropoulos A. Angiopoietin-1 inhibits endothelial permeability, neutrophil adherence and IL-8 production. Br J Pharmacol. 2003; 139:329-36.

108. Xu J, Qu J, Cao L, Sai Y, Chen C, He L, Yu L. Mesenchymal stem cell-based angiopoietin-1 gene therapy for acute lung injury induced by lipopolysaccharide in mice. J Pathol. 2008; 214:472-81.

109. Fang X, Neyrinck AP, Matthay MA, Lee JW. Allogeneic human mesenchymal stem cells restore epithelial protein permeability in cultured human alveolar type II cells by secretion of angiopoietin-1. J Biol Chem. 2010; 285:2621122.

110. Moodley Y, Sturm M, Shaw K, Shimbori C, Tan DB, Kolb M, Graham R. Human mesenchymal stem cells attenuate early damage in a ventilated pig model of acute lung injury. Stem Cell Res (Amst). 2016; 17:25-31.

111. Meirelles LS, Fontes AM, Covas DT, Caplan AI. Mechanisms involved in the therapeutic properties of mesenchymal stem cells. Cytokine Growth Factor Rev. 2009; 20:419-27.

112. Della Latta V, Cecchettini A, Del Ry S, Morales MA. Bleomycin in the setting of lung fibrosis induction: from biological mechanisms to counteractions. Pharmacol Res. 2015; 97:122-30.

113. Wilson JG, Liu KD, Zhuo H, Caballero L, McMillan M, Fang X, Cosgrove K, Vojnik R, Calfee CS, Lee JW, Rogers AJ, Levitt J, Wiener-Kronish J, et al. Mesenchymal stem (stromal) cells for treatment of ARDS: a phase 1 clinical trial. Lancet Respir Med. 2015; 3:24-32.

114. Simonson OE, Mougiakakos D, Heldring N, Bassi G, Johansson HJ, Dalén M, Jitschin R, Rodin S, Corbascio M, El Andaloussi S, Wiklander OP, Nordin JZ, Skog J, et al. In vivo effects of mesenchymal stromal cells in two patients with severe acute respiratory distress syndrome. Stem Cells Transl Med. 2016; 5:845.

115. Zheng G, Huang L, Tong H, Shu Q, Hu Y, Ge M, Deng K, Zhang L, Zou B, Cheng B, Xu J. Treatment of acute respiratory distress syndrome with allogeneic adiposederived mesenchymal stem cells: a randomized, placebocontrolled pilot study. Respir Res. 2014; 15:39.

116. Liu L, He H, Liu A, Xu J, Han J, Chen Q, Hu S, Xu X, Huang Y, Guo F, Yang Y, Qiu H. Therapeutic effects of bone marrow-derived mesenchymal stem cells in models of pulmonary and extrapulmonary acute lung injury. Cell Transplant. 2015; 24:2629-42.

117. Krasnodembskaya A, Samarani G, Song Y, Zhuo H, Su 
X, Lee JW, Gupta N, Petrini M, Matthay MA. Human mesenchymal stem cells reduce mortality and bacteremia in gram-negative sepsis in mice in part by enhancing the phagocytic activity of blood monocytes. Am J Physiol Lung Cell Mol Physiol. 2012; 302:L1003-13.

118. Prockop DJ, Oh JY. Mesenchymal stem/stromal cells (MSCs): role as guardians of inflammation. Mol Ther. 2012; 20:14-20.

119. Ionescu L, Byrne RN, van Haaften T, Vadivel A, Alphonse RS, Rey-Parra GJ, Weissmann G, Hall A, Eaton F, Thébaud B. Stem cell conditioned medium improves acute lung injury in mice: in vivo evidence for stem cell paracrine action. Am J Physiol Lung Cell Mol Physiol. 2012; 303:L967-77.

120. Jun D, Garat C, West J, Thorn N, Chow K, Cleaver T, Sullivan T, Torchia EC, Childs C, Shade T, Tadjali M, Lara A, Nozik-Grayck E, et al. The pathology of bleomycininduced fibrosis is associated with loss of resident lung mesenchymal stem cells that regulate effector T-cell proliferation. Stem Cells. 2011; 29:725-35.

121. Ortiz LA, Dutreil M, Fattman C, Pandey AC, Torres G, Go $\mathrm{K}$, Phinney DG. Interleukin 1 receptor antagonist mediates the antiinflammatory and antifibrotic effect of mesenchymal stem cells during lung injury. Proc Natl Acad Sci USA. 2007; 104:11002-07.

122. Yagi H, Soto-Gutierrez A, Navarro-Alvarez N, Nahmias Y, Goldwasser Y, Kitagawa Y, Tilles AW, Tompkins RG, Parekkadan B, Yarmush ML. Reactive bone marrow stromal cells attenuate systemic inflammation via sTNFR1. Mol Ther. 2010; 18:1857-64.

123. Wisniewski HG, Vilcek J. TSG-6: an IL-1/TNF-inducible protein with anti-inflammatory activity. Cytokine Growth Factor Rev. 1997; 8:143-56.

124. Roddy GW, Oh JY, Lee RH, Bartosh TJ, Ylostalo J, Coble K, Rosa RH Jr, Prockop DJ. Action at a distance: systemically administered adult stem/progenitor cells (MSCs) reduce inflammatory damage to the cornea without engraftment and primarily by secretion of TNF- $\alpha$ stimulated gene/protein 6. Stem Cells. 2011; 29:1572-79.

125. Choi H, Lee RH, Bazhanov N, Oh JY, Prockop DJ. Anti-inflammatory protein TSG-6 secreted by activated MSCs attenuates zymosan-induced mouse peritonitis by decreasing TLR2/NF- $\mathrm{B}$ signaling in resident macrophages. Blood. 2011; 118:330-38.

126. Jarvinen L, Badri L, Wettlaufer S, Ohtsuka T, Standiford TJ, Toews GB, Pinsky DJ, Peters-Golden M, Lama VN. Lung resident mesenchymal stem cells isolated from human lung allografts inhibit $\mathrm{T}$ cell proliferation via a soluble mediator. J Immunol. 2008; 181:4389-96.

127. Dackor RT, Cheng J, Voltz JW, Card JW, Ferguson CD, Garrett RC, Bradbury JA, DeGraff LM, Lih FB, Tomer KB, Flake GP, Travlos GS, Ramsey RW Jr, et al. Prostaglandin $\mathrm{E}_{2}$ protects murine lungs from bleomycin-induced pulmonary fibrosis and lung dysfunction. Am J Physiol Lung Cell Mol Physiol. 2011; 301:L645-55.
128. Lee BC, Kim HS, Shin TH, Kang I, Lee JY, Kim JJ, Kang HK, Seo Y, Lee S, Yu KR, Choi SW, Kang KS. PGE2 maintains self-renewal of human adult stem cells via EP2mediated autocrine signaling and its production is regulated by cell-to-cell contact. Sci Rep. 2016; 6:26298.

129. Han J, Lu X, Zou L, Xu X, Qiu H. E-prostanoid 2 receptor overexpression promoted mesenchymal stem cell attenuated lung injury. Hum Gene Ther. 2016; 27:621-30.

130. Kim J, Hematti P. Mesenchymal stem cell-educated macrophages: a novel type of alternatively activated macrophages. Exp Hematol. 2009; 37:1445-53.

131. Maggini J, Mirkin G, Bognanni I, Holmberg J, Piazzón IM, Nepomnaschy I, Costa H, Cañones C, Raiden S, Vermeulen M, Geffner JR. Mouse bone marrow-derived mesenchymal stromal cells turn activated macrophages into a regulatorylike profile. PLoS One. 2010; 5:e9252.

132. Zhang QZ, Su WR, Shi SH, Wilder-Smith P, Xiang AP, Wong A, Nguyen AL, Kwon CW, Le AD. Human gingivaderived mesenchymal stem cells elicit polarization of $\mathrm{m} 2$ macrophages and enhance cutaneous wound healing. Stem Cells. 2010; 28:1856-68.

133. Feghali-Bostwick CA, Tsai CG, Valentine VG, Kantrow S, Stoner MW, Pilewski JM, Gadgil A, George MP, Gibson KF, Choi AM, Kaminski N, Zhang Y, Duncan SR. Cellular and humoral autoreactivity in idiopathic pulmonary fibrosis. J Immunol. 2007; 179:2592-99.

134. Galati D, De Martino M, Trotta A, Rea G, Bruzzese D, Cicchitto G, Stanziola AA, Napolitano M, Sanduzzi A, Bocchino M. Peripheral depletion of NK cells and imbalance of the Treg/Th17 axis in idiopathic pulmonary fibrosis patients. Cytokine. 2014; 66:119-26.

135. Burlingham WJ, Love RB, Jankowska-Gan E, Haynes LD, Xu Q, Bobadilla JL, Meyer KC, Hayney MS, Braun RK, Greenspan DS, Gopalakrishnan B, Cai J, Brand DD, et al. IL-17-dependent cellular immunity to collagen type $\mathrm{V}$ predisposes to obliterative bronchiolitis in human lung transplants. J Clin Invest. 2007; 117:3498-506.

136. Vittal R, Mickler EA, Fisher AJ, Zhang C, Rothhaar K, Gu H, Brown KM, Emtiazdjoo A, Lott JM, Frye SB, Smith GN, Sandusky GE, Cummings OW, Wilkes DS. Type V collagen induced tolerance suppresses collagen deposition, TGF- $\beta$ and associated transcripts in pulmonary fibrosis. PLoS One. 2013; 8:e76451.

137. Wilkes DS, Chew T, Flaherty KR, Frye S, Gibson KF, Kaminski N, Klemsz MJ, Lange W, Noth I, Rothhaar K. Oral immunotherapy with type $\mathrm{V}$ collagen in idiopathic pulmonary fibrosis. Eur Respir J. 2015; 45:1393-402.

138. Wright JR. Immunoregulatory functions of surfactant proteins. Nat Rev Immunol. 2005; 5:58-68.

139. Barlo NP, van Moorsel CH, Ruven HJ, Zanen P, van den Bosch JM, Grutters JC. Surfactant protein-D predicts survival in patients with idiopathic pulmonary fibrosis. Sarcoidosis Vasc Diffuse Lung Dis. 2009; 26:155-61.

140. Kinder BW, Brown KK, McCormack FX, Ix JH, Kervitsky 
A, Schwarz MI, King TE Jr. Serum surfactant protein-A is a strong predictor of early mortality in idiopathic pulmonary fibrosis. Chest. 2009; 135:1557-63.

141. Aono Y, Ledford JG, Mukherjee S, Ogawa H, Nishioka Y, Sone S, Beers MF, Noble PW, Wright JR. Surfactant protein-D regulates effector cell function and fibrotic lung remodeling in response to bleomycin injury. Am J Respir Crit Care Med. 2012; 185:525-36.

142. Ren G, Zhang L, Zhao X, Xu G, Zhang Y, Roberts AI, Zhao RC, Shi Y. Mesenchymal stem cell-mediated immunosuppression occurs via concerted action of chemokines and nitric oxide. Cell Stem Cell. 2008; 2:14150.

143. Ren G, Zhao X, Zhang L, Zhang J, L'Huillier A, Ling W, Roberts AI, Le AD, Shi S, Shao C, Shi Y. Inflammatory cytokine-induced intercellular adhesion molecule-1 and vascular cell adhesion molecule-1 in mesenchymal stem cells are critical for immunosuppression. J Immunol. 2010; 184:2321-28.

144. Shi Y, Su J, Roberts AI, Shou P, Rabson AB, Ren G. How mesenchymal stem cells interact with tissue immune responses. Trends Immunol. 2012; 33:136-43.

145. Sato K, Ozaki K, Oh I, Meguro A, Hatanaka K, Nagai T, Muroi K, Ozawa K. Nitric oxide plays a critical role in suppression of T-cell proliferation by mesenchymal stem cells. Blood. 2007; 109:228-34.

146. Rasmusson I, Le Blanc K, Sundberg B, Ringdén O. Mesenchymal stem cells stimulate antibody secretion in human B cells. Scand J Immunol. 2007; 65:336-43.

147. Bouffi C, Bony C, Courties G, Jorgensen C, Noël D. IL6-dependent PGE2 secretion by mesenchymal stem cells inhibits local inflammation in experimental arthritis. PLoS One. 2010; 5:e14247.

148. Bustos ML, Huleihel L, Kapetanaki MG, Lino-Cardenas CL, Mroz L, Ellis BM, McVerry BJ, Richards TJ, Kaminski N, Cerdenes N, Mora AL, Rojas M. Aging mesenchymal stem cells fail to protect because of impaired migration and antiinflammatory response. Am J Respir Crit Care Med. 2014; 189:787-98.

149. Nemeth K, Keane-Myers A, Brown JM, Metcalfe DD, Gorham JD, Bundoc VG, Hodges MG, Jelinek I, Madala S, Karpati S, Mezey E. Bone marrow stromal cells use TGFbeta to suppress allergic responses in a mouse model of ragweed-induced asthma. Proc Natl Acad Sci USA. 2010; 107:5652-57.

150. Liu M, Zeng X, Wang J, Fu Z, Wang J, Liu M, Ren D, Yu B, Zheng L, Hu X, Shi W, Xu J. Immunomodulation by mesenchymal stem cells in treating human autoimmune disease-associated lung fibrosis. Stem Cell Res Ther. 2016; $7: 63$.

151. Rubtsov YP, Rudensky AY. TGFbeta signalling in control of T-cell-mediated self-reactivity. Nat Rev Immunol. 2007; 7:443-53.

152. Pourgholaminejad A, Aghdami N, Baharvand $\mathrm{H}$,
Moazzeni SM. The effect of pro-inflammatory cytokines on immunophenotype, differentiation capacity and immunomodulatory functions of human mesenchymal stem cells. Cytokine. 2016; 85:51-60.

153. Lötvall J, Hill AF, Hochberg F, Buzás EI, Di Vizio D, Gardiner C, Gho YS, Kurochkin IV, Mathivanan S, Quesenberry P, Sahoo S, Tahara H, Wauben MH, et al. Minimal experimental requirements for definition of extracellular vesicles and their functions: a position statement from the International Society for Extracellular Vesicles. J Extracell Vesicles. 2014; 3:26913.

154. Camussi G, Deregibus MC, Bruno S, Cantaluppi V, Biancone L. Exosomes/microvesicles as a mechanism of cell-to-cell communication. Kidney Int. 2010; 78:838-48.

155. Baglio SR, Pegtel DM, Baldini N. Mesenchymal stem cell secreted vesicles provide novel opportunities in (stem) cellfree therapy. Front Physiol. 2012; 3:359.

156. Lai RC, Tan SS, Yeo RW, Choo AB, Reiner AT, Su Y, Shen Y, Fu Z, Alexander L, Sze SK, Lim SK. MSC secretes at least $3 \mathrm{EV}$ types each with a unique permutation of membrane lipid, protein and RNA. J Extracell Vesicles. 2016; 5:29828.

157. Ramos TL, Sánchez-Abarca LI, Muntión S, Preciado S, Puig N, López-Ruano G, Hernández-Hernández Á, Redondo A, Ortega R, Rodríguez C, Sánchez-Guijo F, del Cañizo C. MSC surface markers (CD44, CD73, and CD90) can identify human MSC-derived extracellular vesicles by conventional flow cytometry. Cell Commun Signal. 2016; $14: 2$.

158. Akyurekli C, Le Y, Richardson RB, Fergusson D, Tay J, Allan DS. A systematic review of preclinical studies on the therapeutic potential of mesenchymal stromal cell-derived microvesicles. Stem Cell Rev. 2015; 11:150-60.

159. Abreu SC, Weiss DJ, Rocco PR. Extracellular vesicles derived from mesenchymal stromal cells: a therapeutic option in respiratory diseases? Stem Cell Res Ther. 2016; 7:53.

160. Pachler K, Lener T, Streif D, Dunai ZA, Desgeorges A, Feichtner M, Öller M, Schallmoser K, Rohde E, Gimona M. A Good Manufacturing Practice-grade standard protocol for exclusively human mesenchymal stromal cell-derived extracellular vesicles. Cytotherapy. 2017; 19:458-72.

161. Yu SH, Liu LJ, Lv B, Che CL, Fan DP, Wang LF, Zhang YM. Inhibition of bleomycin-induced pulmonary fibrosis by bone marrow-derived mesenchymal stem cells might be mediated by decreasing MMP9, TIMP-1, INF- $\gamma$ and TGF- $\beta$. Cell Biochem Funct. 2015; 33:356-66.

162. Mei SH, Haitsma JJ, Dos Santos CC, Deng Y, Lai PF, Slutsky AS, Liles WC, Stewart DJ. Mesenchymal stem cells reduce inflammation while enhancing bacterial clearance and improving survival in sepsis. Am J Respir Crit Care Med. 2010; 182:1047-57.

163. Ni S, Wang D, Qiu X, Pang L, Song Z, Guo K. Bone marrow mesenchymal stem cells protect against bleomycin- 
induced pulmonary fibrosis in rat by activating $\mathrm{Nrf} 2$ signaling. Int J Clin Exp Pathol. 2015; 8:7752-61.

164. Zhao YD, Huang X, Yi F, Dai Z, Qian Z, Tiruppathi C, Tran K, Zhao YY. Endothelial FoxM1 mediates bone marrow progenitor cell-induced vascular repair and resolution of inflammation following inflammatory lung injury. Stem Cells. 2014; 32:1855-64.

165. Ono M, Ohkouchi S, Kanehira M, Tode N, Kobayashi M, Ebina M, Nukiwa T, Irokawa T, Ogawa H, Akaike T, Okada Y, Kurosawa H, Kikuchi T, Ichinose M. Mesenchymal stem cells correct inappropriate epithelial-mesenchyme relation in pulmonary fibrosis using stanniocalcin-1. Mol Ther. 2015; 23:549-60.

166. Kim PH, Na SS, Lee B, Kim JH, Cho JY. Stanniocalcin 2 enhances mesenchymal stem cell survival by suppressing oxidative stress. BMB Rep. 2015; 48:702-07.

167. Ahmad T, Mukherjee S, Pattnaik B, Kumar M, Singh S, Kumar M, Rehman R, Tiwari BK, Jha KA, Barhanpurkar AP, Wani MR, Roy SS, Mabalirajan U, et al. Miro1 regulates intercellular mitochondrial transport \& enhances mesenchymal stem cell rescue efficacy. EMBO J. 2014; 33:994-1010.

168. Kurowska-Stolarska M, Hasoo MK, Welsh DJ, Stewart L, McIntyre D, Morton BE, Johnstone S, Miller AM, Asquith DL, Millar NL, Millar AB, Feghali-Bostwick CA, Hirani N, et al. The role of microRNA-155/liver X receptor pathway in experimental and idiopathic pulmonary fibrosis. J Allergy Clin Immunol. 2017; 139:1946-56. 